\title{
A REVIEW OF THE SUBGENUS TRICHOPYGOMYIA BARRETTO, 1962; WITH DESCRIPTION OF A NEW SPECIES FROM THE BRAZILIAN AMAZON BASIN (DIPTERA: PSYCHODIDAE, PHLEBOTOMINAE)
}

\author{
JORGE R. ARIAS* \\ PAUL D. READY** \\ RUI A. DE FREITAS*
}

The subgenus Trichopygomyia Barretto, 1962 of the phlebotomine genus Lutzomyia França, 1924 is reviewed. This subgenus corresponds to the informal species group longispina of Theodor (1965). Lutzomyia (Trichopygomyia) ratcliffei $n$. sp. from the Brazilian Amazon Basin is described. Figures, keys, distribution maps and notes on ecology are presented for all the known forms. The better known species are most frequently encountered in armadillo burrows and, therefore, could well be vectors of Leishmania.

\section{CLASSIFICATION}

Genus Lutzomyia França, 1924 (sensu Theodor, 1948, 1965).

Subgenus Trichopygomyia Barretto, 1962.

Antennal ascoids simple (i.e. without hind spurs) and long. Fifth palpal segment as long as, or longer than, the combined length of segments 3 and 4. Male: Style (=dististylus) not forked, bearing four major spines inserted at different levels and a subterminal seta. Coxite (=basistylus) without a median or basal discrete tuft of setae but with a narrow row of long, semideciduous setae along its ventral margin. Paramere bifurcate or trifurcate. Aedeagus large. Lateral lobe not swollen and as long as coxite. Female: Body of spermatheca ovoid (or pear shaped), finely striated, with a prominent terminal knob (or "head"); individual spermathecal duct distinct, of ten long; common spermathecal duct long, short or absent. Cibarium (= buccal cavity) typically with 4 horizontal teeth and one or two rows of small vertical (= fore) teeth; cibarial arch complete or nearly so; pigment patch often weakly marked. Egg: with polygonal pattern on exochorion. Larvae: antennae not on prominent tubercles; 1 st instar with 2 caudal setae, 2 nd to 4 th instars with 4.

This investigation received financial support from the UNDP/World Bank/WHO Special Programme for Research and Training in Tropical Diseases, CNPq's Grandes Endemias grant n? 222.8.987/80 and The Wellcome Trust, London.

*Instituto Nacional de Pesquisas da Amazônia, Caixa Postal 478, 69000, Manaus, Amazonas, Brazil.

* *Wellcome Parasitology Unit, Caixa Postal 3, 66000, Belém, Pará, Brazil. 
Barretto (1962) created Trichopygomyia as a subgenus of Lutzomyia, with Flebotomus longispinus Mangabeira, 1942 as its type species. Of the species listed by Barretto (1962), Lutzomyia dasipodogeton (Castro), L. longispina (Mangabeira), L. trichopyga (Floch \& Abonnenc), L. triramula (Fairchild \& Hertig) and L. wagleyi (Causey \& Damasceno) constitute a "natural" group, in that the adults of each sex share a combination of morphological characters which separates them from other neotropical sand flies; Lutzomyia (Lutzomyia) lichyi (Floch \& Abonnenc, 1950), the six th species listed by Barretto (1962), is clearly different (the male has two foliaceous setae on a coxite tubercle; the female has annulate spermathecae). Fairchild \& Hertig (1952) were the first to associate the aforementioned five species, which Fairchild (1955) later classified as the informal species group longispinus. The advantages of using informal sub-generic groups for the genus Lutzomyia sensu lato have been further advocated by Theodor (1965), Lewis et al. (1977) and Young (1979), all of whom recognized Fairchild's species group as longispina. Martins and colleagues, however, accepted Barretto's formal subgeneric ranking (Martins et al., 1963, 1965, 1976, 1978; Ramirez-Perez et al., 1976).

The failure to formalize groups of neotropical phlebotomine sand flies has hindered information retrieval and communication to such a degree that Forattini (1971, 1973) felt obliged to propose a radical, and admittedly artificial, classification in which the subgenus Trichopygomyia contained 37 species of very variable adult morphology. In our opinion, wherever possible, formal genus-group names should be adopted in order to aid communication and to main tain the integrity of long-recognized "natural" groups (see Ready et al., 1981). Thus, the subgenus considered here is Trichopygomyia sensu stricto, following the definitions of Barretto (1962) and Martins et al. (1978).

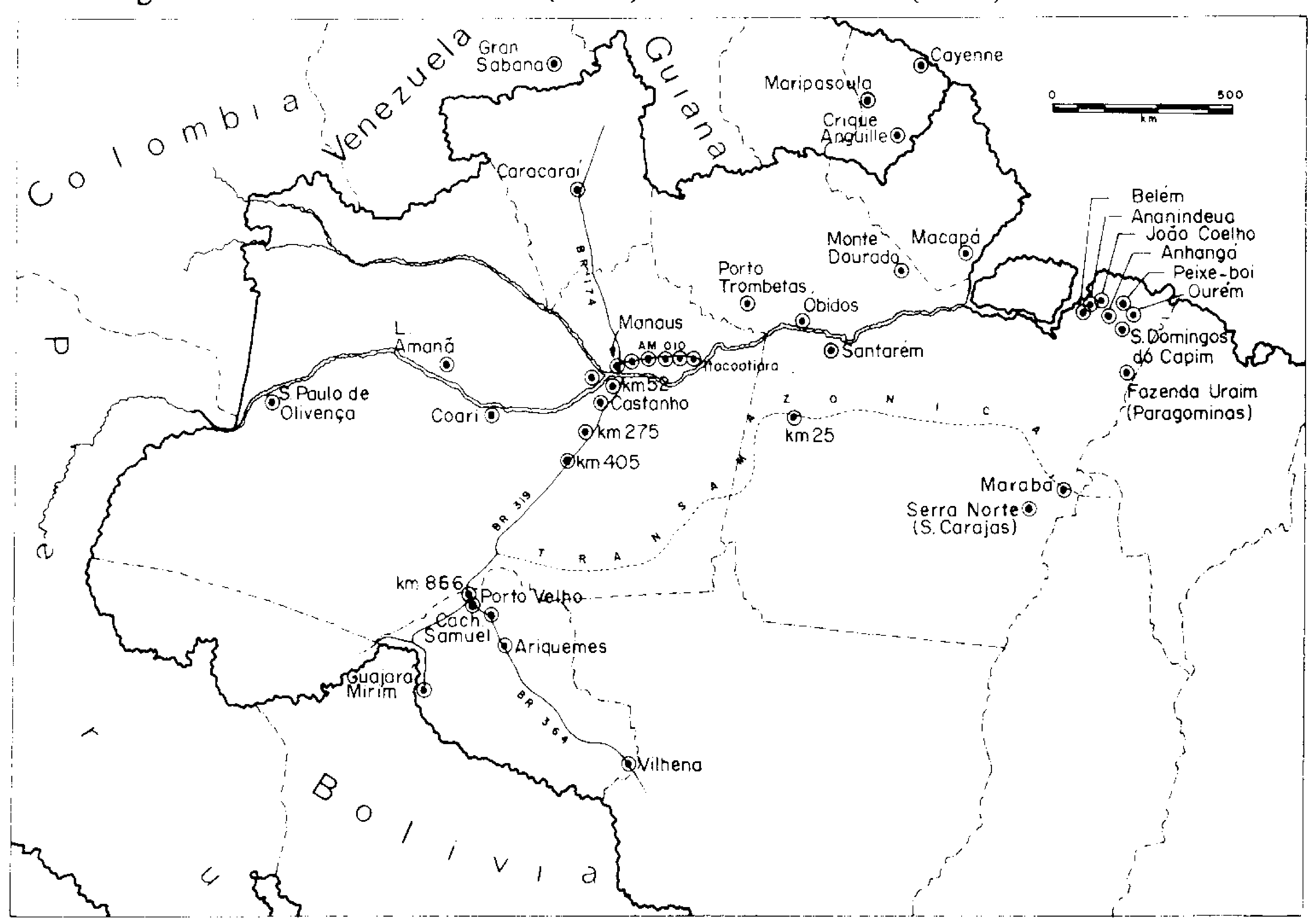

Map. 1 - Northern Brazil and neighbouring countries showing localities cited as collection records for the various sand fly species in the subgenus Trichopygomyia.

The new species described in this paper brings the total in the subgenus to nine; L. rondoniensis Martins, Falcão \& Silva, L. elegans Martins, Llanos \& Silva and L. conviti Ramirez-Perez, Martins \& Perez were added to the original group by their describers. Lutzomyia triramula is the only trans-Andean species, having been recorded from non Amazonian Colombia to Belize; the other eight species are known only from east of the 
Andes (cis-Andean), all occurring in or near the Amazon Basin (six have been captured in the Brazilian Amazon region). All measurements are in $\mathrm{mm}$.

\section{Lutzomyia conviti Ramirez-Perez, Martins \& Perez, 1976}

(Fig. 1) Venezuela).

Lutzomyia conviti Ramirez-Perez, Martins \& Ramirez, 1976 ( 89 described from

\section{Distribution. Venezuela - Amazonas: Ocamo}

\section{Material Examined. None}

Discussion. This species closely resembles Lutzomyia rondoniensis and could possibly be conspecific. Unfortunately, we were not able to examine any specimens and the original description and illustrations could fit some of our $L$. rondoniensis. More collections in both the Venezuelan and Brazilian Amazon will probably clarify its status. The difference in the forms of the aedeagus does separate these two species, and at least for the present, we treat them as distinct species.

\section{Lutzomyia dasipodogeton (Castro, 1939)}

(Fig. 2; map 2)

Flebotomus dasipodogeton Castro, 1939:4 (đ described from Abaeté, Pará, Brazil). Mangabeira, 1942a:189 (cf. to longispinus).

Phlebotomus dasipodogeton: Floch \& Abonnenc, 1945:3 (cf. to trichopygus). Floch \& Abonnenc, 1952:33 (keyed). Fairchild \& Hertig, 1952:518 (cf. to triramulus). Fairchild, 1955:195 (classified).

Lutzomyia dasipodogeton: Forattini, 1971:102 (classified). Forattini, 1973: 303 et. seq. (gen. review, figs.). Martins et al.. 1978: 114 (listed, distribution).

Lutzomyia dasypodogeton (sic): Barretto, 1962: 98 (classified). Martins et al. 1965: 14 (cf. to rondoniensis). Theodor, 1965: 190 (classified). Lewis, 1975:502 et seq. (mouthpart morph.). Ramirez-Perez et al., 1976:601 (cf. to conviti). Martins et al., 1983: (redescribed).

Distribution. Brazil -- Amazonas State: AM-010 (Manaus - Itacoatiara) Kms 133 \& 246, $2 \delta \delta$ in CDC light traps 14-III-79. (Arias et al. coll); BR-319 (Manaus-Porto Velho) Kms. 52 \& 102, 5 ơ in CDC light traps, various dates 1980-81 (Ibid). Pará State: Ananindeua, $124 \delta \delta$ in animal burrows (most) and on tree trunks, various dates 1942-45 (Damasceno et al., 1949:823, 840); Anhanga, $810 \$ 0$ same information (Ibid). Belém, 4,149 đo same information (Ibid); João Coelho, 50 do same information (Ibid); Ourém, 2,238 o $\delta$ same information (Ibid); Peixe Boi. 177 o $\delta$ same information (Ibid); Santarém, $45 \delta \delta$, same information (Ibid); São Domingo do Capim, 2,100 o $\delta$, same information (Ibid); Fazenda Uraim (130 Km east of Paragominas), 680 in CDC light traps. April 1981 (P.D. Ready coll.); Itaituba-Altamira Km 25, $3308,89 \%$ in an armadillo burrow, November 1971 (R.D. Ward coll.); near Monte Dourado, 1 o on tree trunk, November 1975 (R.D. Ward coll.); Serra Norte, Serra dos Carajás, 2 o 8 from rodent-baited Disney trap (Ward et al., 1973:178), ojç very abundant in CDC light traps, in armadillo burrows and on forest floor at altitudes $200-600 \mathrm{~m}$ above sea level, various dates 1982 (P.D. Ready coll.). Rondónia State: BR-319 (Manaus-Porto Velho) Km 866 on west bank of Rio Madeira, $\delta d$ frequent in CDC light traps, various dates 1980-81 (Biancardi et al., 1982:168 et seq.); BR-316 (Porto Velho-Vilhena) Kms 8, 19, 48, 62, 181, \& Vilhena, oú frequent in CDC light traps (Ibid). Roraima Federal Territory: Caracaraí, 2 do [on tree trunks] December 1960 (Martins et al., 1963:334). 


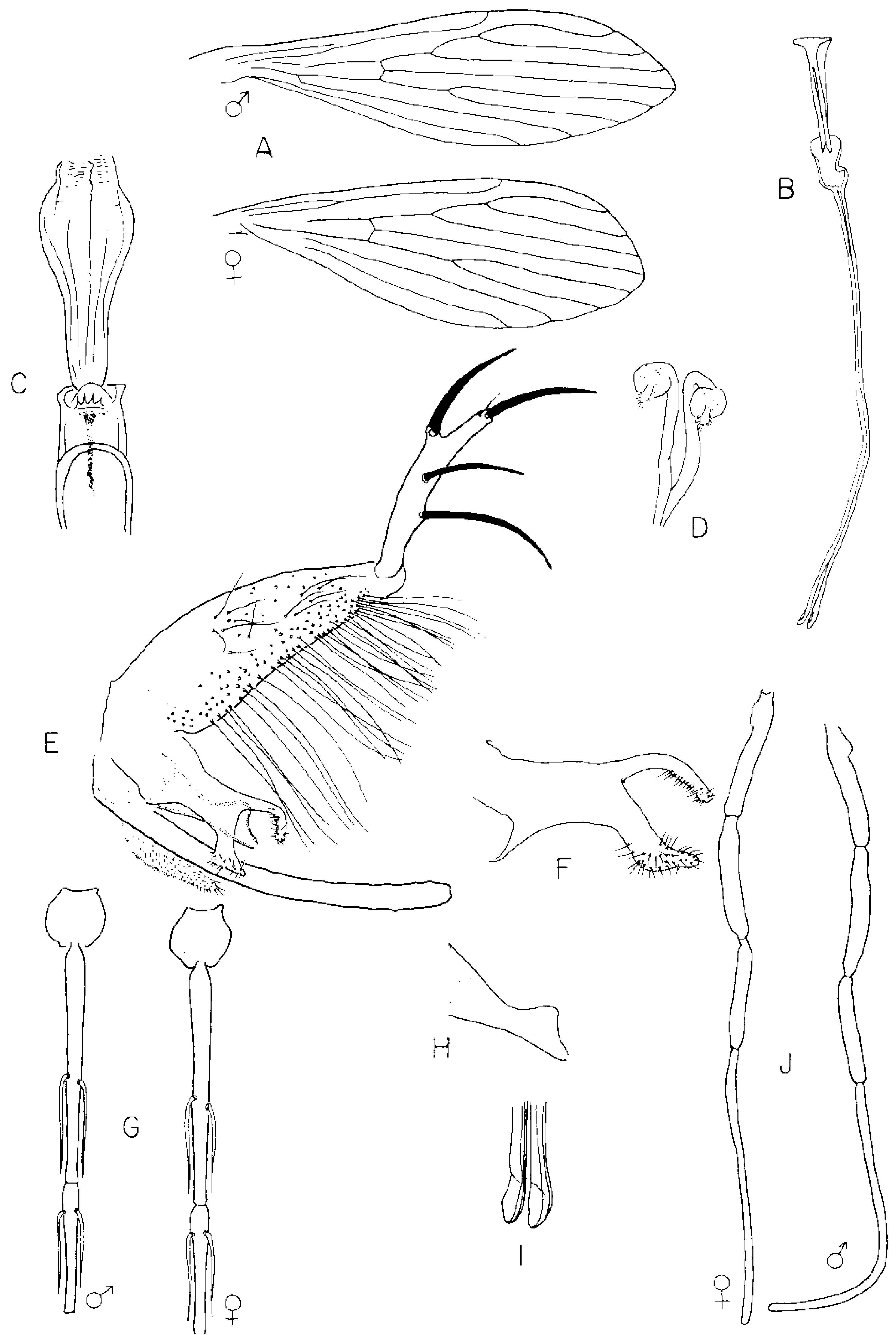

Fig. 1 -Lutzomyia conviti: A, wings; B, genital pump with filaments; C, 9 cibarium and pharynx: $D$, spermathecae with ducts; $\mathrm{F}$, ot genitalia; $F$, paramere; $G$, bases of an tennae; $H$, aedeagus; 1 , genital filament tips and J, palps. (all af ter Ramirez-Perez et al., 1976). 


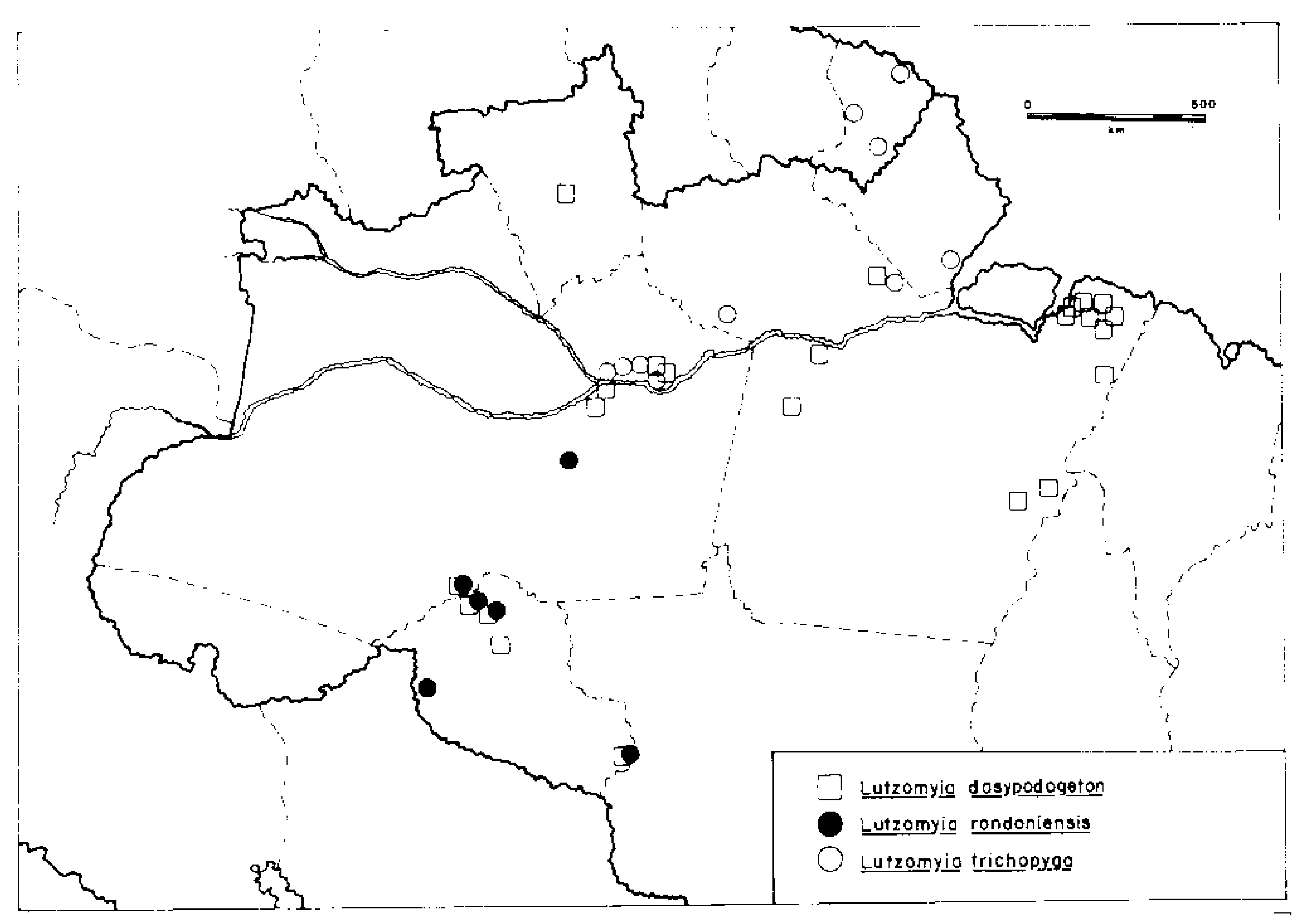

Map. 2 - Known geographical distribution of Lutzomyia dasipodogeton, L. trichopyga and L. rondoniensis.

Material examined. Over 100 of from the various localities in Amazonas and Rondônia States. On various occasions during the period June - October 1982, large numbers $(50+$ of each sex $)$ of this species were taken from CDC light traps set at different altitudes (200-600m a.s.l.) in the region of Serra Norte, Pará State. No other Trychopygomyia forms were captured at the same times, thereby allowing us to associate the sexes of I. dasipodogeton.

\section{Lutzomyia elegans Martins, Llanos \& Silva, 1976 (Fig. 3)}

Lutzomvia elegans Martins, Llanos \& Silva, 1976 ( $\delta, ~ \&$ described from Cachicoto, Huanuco, Peru). Martins et al., 1978): 114 (listed, distribution).

Distribution. Peru - Huanuco, Cachicoto, 124 of $20 \% q$ in animal burrows (Martins et al., 1976).

Material examined. 1 o (Paratype) Cachicoto, Huanuco, (Peru) 14.7.73, A.V. Martins (slide no 47.611 NE no 01943/73). 1 \& Cachicoto, Huanuco (Peru) 14.7.73, J. Evangelista da Silva \& Bertha Llanos coll. (slide no 1565 and 1363). 1 ( (paratype) same locality and date A.V. Martins coll. (slide no 47.684. NE n? 1943/73).

Discussion. This species is known only from Peru but may occur in the western most part of the Brazilian Amazon, near the Andes. It has not been taken with any other species in this subgenus. L. elegans is most closcly related to Latzomyia triramula which occurs in the western part of Colombia, but not in Brazil. Both species are easily separated from other Trichopygomvia males by their trifurcated parameres, the dorsal arms of which are subcylindrical and bear a distal tuft of curved setae. Males of these two species are separated from each other by the strucure of the paramere (cf. Fig. 3 \& Fig. 9 ). 

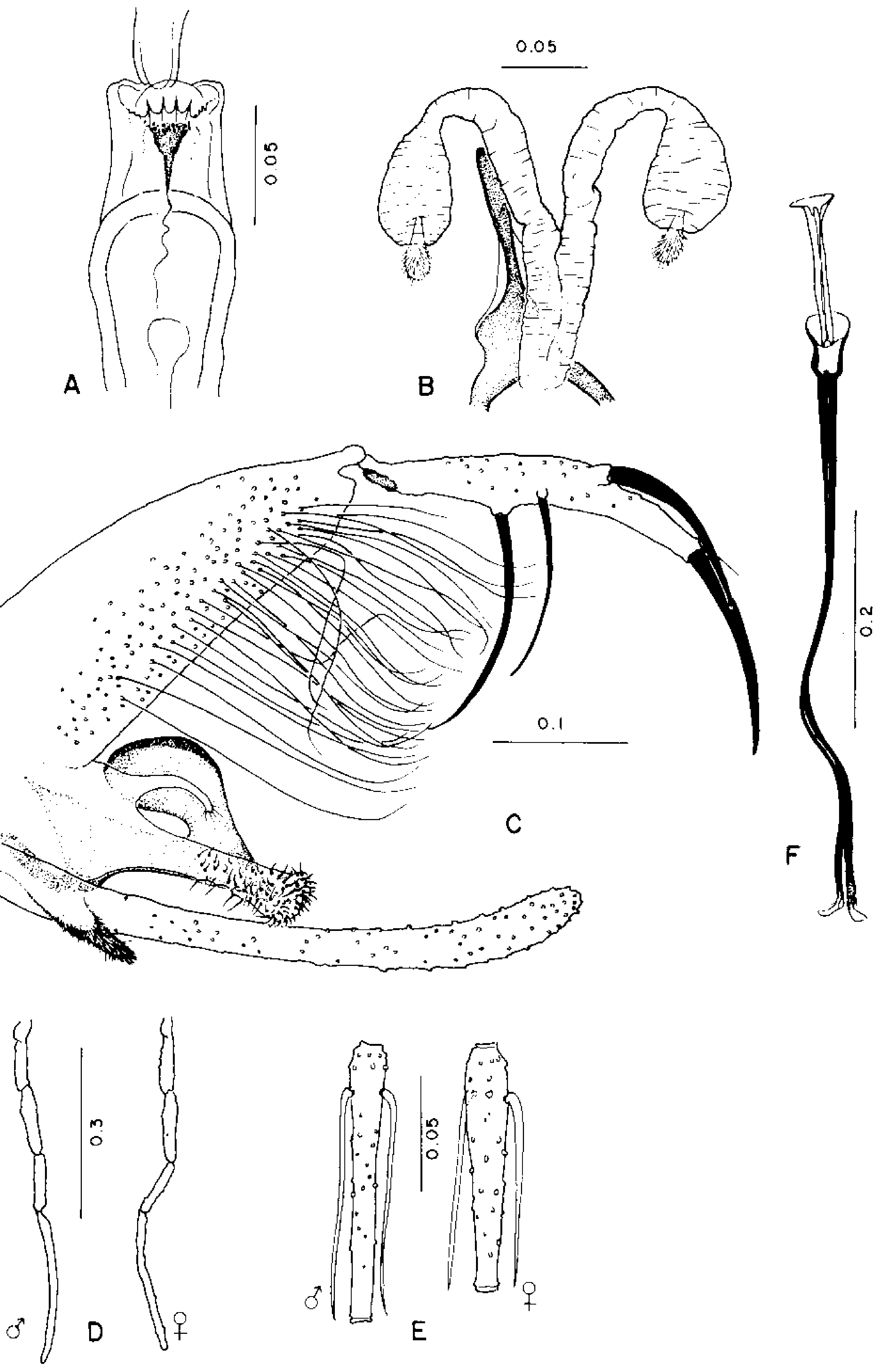

Fig. $2 \cdots$ Lutzomyia dasipodogeton; A, 9 cibarium; B, spermathecae with ducts; C, d genitalia; D, palps; $E$, Il flagellomere; $F$, genital pump with filaments. 


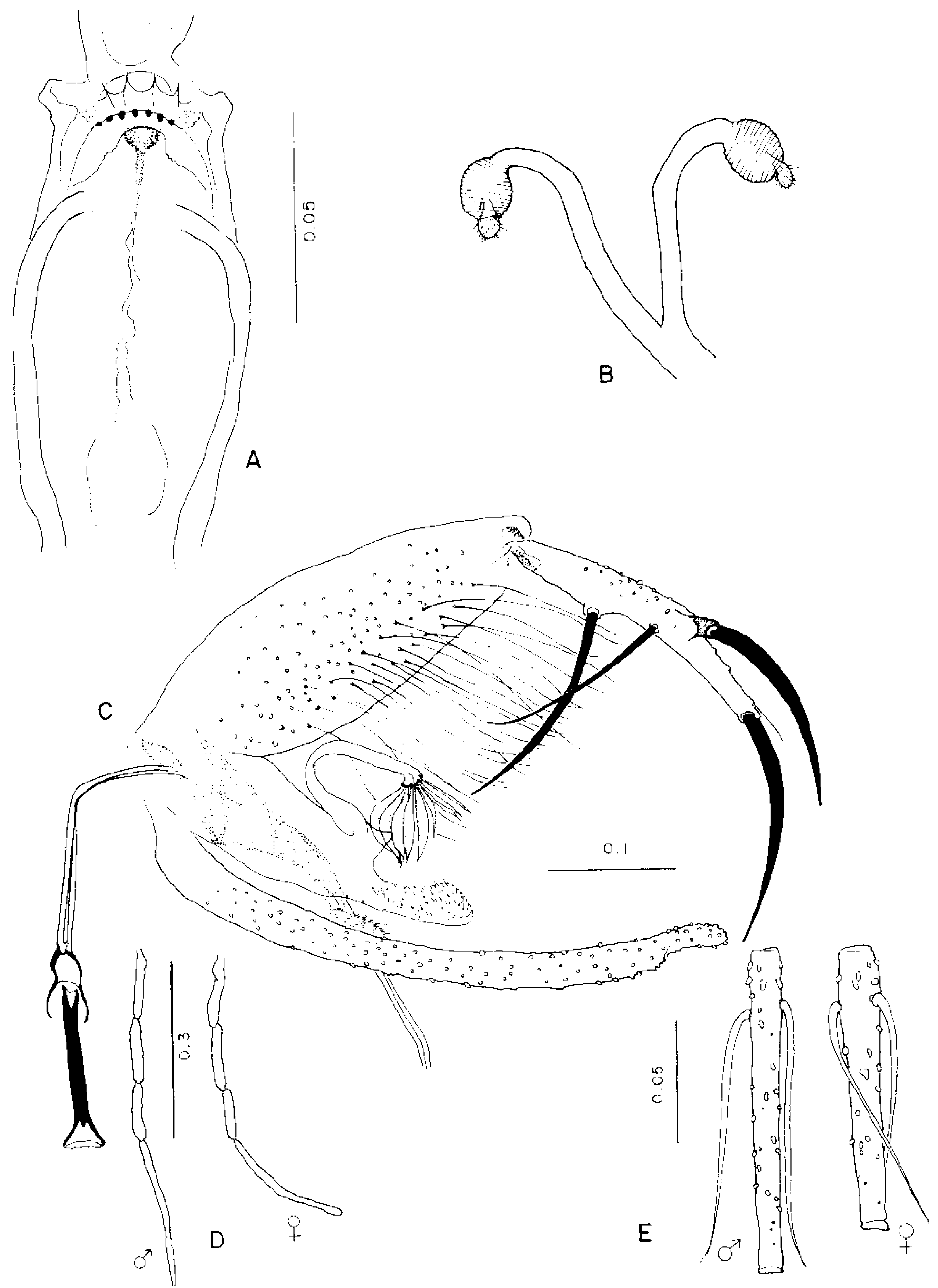

Fig. 3 -Lutzomyia elegans: A, 9 cibarium; B, spermathecae with ducts (after Martins et al., 1975); C, male genitalia; D, palps; E, flagellomere II. 


\section{Lutzomyia longispina (Mangabeira, 1942)}

(Fig. 4 \& 5; map 3)

Flebotomus longispinus Mangabeira, 1942a. 186-189 (o holotype described from Aurá, Belém, Pará). Mangabeira, 1942b: 251 et seq. ( $\$$, egg and larvae described). Causey \& Damasceno, 1945a: 29 (cf. to wagleyi).

Phlebotomus longispinus: Floch \& Abonnenc, 1945: 3 (cf. to trichopygus). Vargas \& Diaz-Najera, 1951: 22 (cf. to pratti). Floch \& Abonnenc, 1952: 48 (ơ keyed). Fairchild \& Hertig, 1952: 518 (cf. to triramulus). Fairchild, 1955: 195 (classified). Pifano et al., 1962: 385, 389 (¿q keyed). Hanson, 1968: 88 (larva cf. to triramulus).

Lutzomyia longispina: Barretto, 1962 (classified). Martins et al., 1965: 14 (cf. to rondoniensis). Theodor, 1965: 190 (classified, of figs.). Forattini 1971: 101-102 (classified). Forattini, 1973: 309 et seq. (gen. review, figs.). Lewis, 1975: 502 et seq. (mouthpart morph.). Martins et al., 1976:491 (cf. to elegans). Ramirez-Perez et al., 1976:602 (cf. to conviti). Léger et al., 1977:218, 224 ( 9 fig., Fr. Guiana). Martins et al., 1978: 114 (listed, distribution). Young, 1979: 121-123 (listed, distribution, $\delta \circ$ figs., $\mathrm{cf}$. to triramula in Colombia).

Distribution. [Colombia - Caqueta Department: San Miguel, $1 \&$ in tree hole (Osorno et al., 1972: 57)]. ${ }^{*}$ [Venezuela - Bolivar State: Gran Sabana (Pifano \& Ortiz, 1952:142)]. Brazil - Amazonas State: Coari, 15 ơ in animal burrows (most) and on tree trunks, various date 1942-45 (Damasceno et al., 1949: 827-841); Manacapuru, $698 \delta^{*} \delta^{*}$, same information (Ibid); Parintins, 3,254 $\delta^{\circ} \delta^{\prime}$, same information (Ibid); Lago

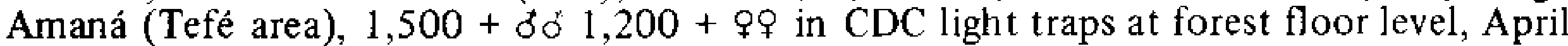
1981 (J.R. Arias et al. coll); BR.319 (Manaus - Porto Velho) kms. 52 \& 100, 39 o 8 in CDC light traps and on tree bases, various dates 1979-80 (lbid). Bahia State: Cacheira, of in armadillo burrow (Sherlock \& Pessoa, 1964: 333). [Minas Gerais State: Marlieria, from Martins et al. 1978]. Pará State: Aurá, $6300^{\circ}$ in armadillo burrows (Mangabeira, 1942a: 189); Anhanga, $40 \delta^{\circ} \delta^{*}$ in animal burrows (most) and on tree trunks, various dates 194245 (Damasceno et al., 1949: 827); Belém, 37,967 d̊d, same information (Ibid); João Coetho, $74 \delta \delta$, same information (Ibid), Obidos, $5 \delta \delta$, same information (Ibid); Santarém, $17 \delta^{\circ}$ same information (Ibid); São Domingos do Capim, $1 \delta$, same information (Ibid); Utinga (Belém), 662 ơ 132 o f from armadillo burrow(s), 1970-74 (R.D. Ward coll). [Pernambuco State: Igaraçú, from Martins et al., 1978]. Rondônia State: BR-319 (Manaus - Porto Velho) km 866,7 $\delta^{\circ}$ in CDC light trap on west bank of Rio Madeira (Biancardi et al., 1982:172). [French Guiana - near Cayenne, I $\$$ (Léger et al., 1977; 218, 224); Maripasoula, 4 $९$ (Ibid)].

Material examined. All $\delta \delta^{*}$ from BR-319 and $1,000+\delta \delta \& q q$ from Lago Amanã. Drawing of female based on female caught in same traps as the Lago Amanã males; no other Trichopygomyia forms were taken in the same locality.

Discussion. Within the Amazon Basin this specics has only been taken in lowland sites, where it is known to be sympatric with $L$. dasipodogeton, $L$. rondoniensis and $L$. wagleyi. The male of $L$. longispina is morphologically closest to those of $L$. ratcliffei and $L$. wagleyi, from which it can be separated on features of the parameres (Fig. 4). Records of this species based solely on females should be treated with caution as, judged by male characters, the females of $L$. ratcliffei and $L$. wagleyi are probably very similar. Intraspecific variation in size of $L$. longispina from different localities was noted.

\section{Lutzomyia ratcliffei $\mathrm{n} . \mathrm{sp}$.}

(Figs. 4 \& 6; map 3)

Measurements outside the brackets refer to the holotype, within the brackets is the variation found in 5 paratypes.

Male. Wing length $2.00(1.98-2.11)$; width $0.51(0.58-0.59)$. Entire insect moderately pigmented, the pleura lighter than the nota. Head height from vertex to tip of

*Until all the $\$ 9$ of the subgenus have been described records not based on $\delta \sigma,[]$, are best treated with caution. 


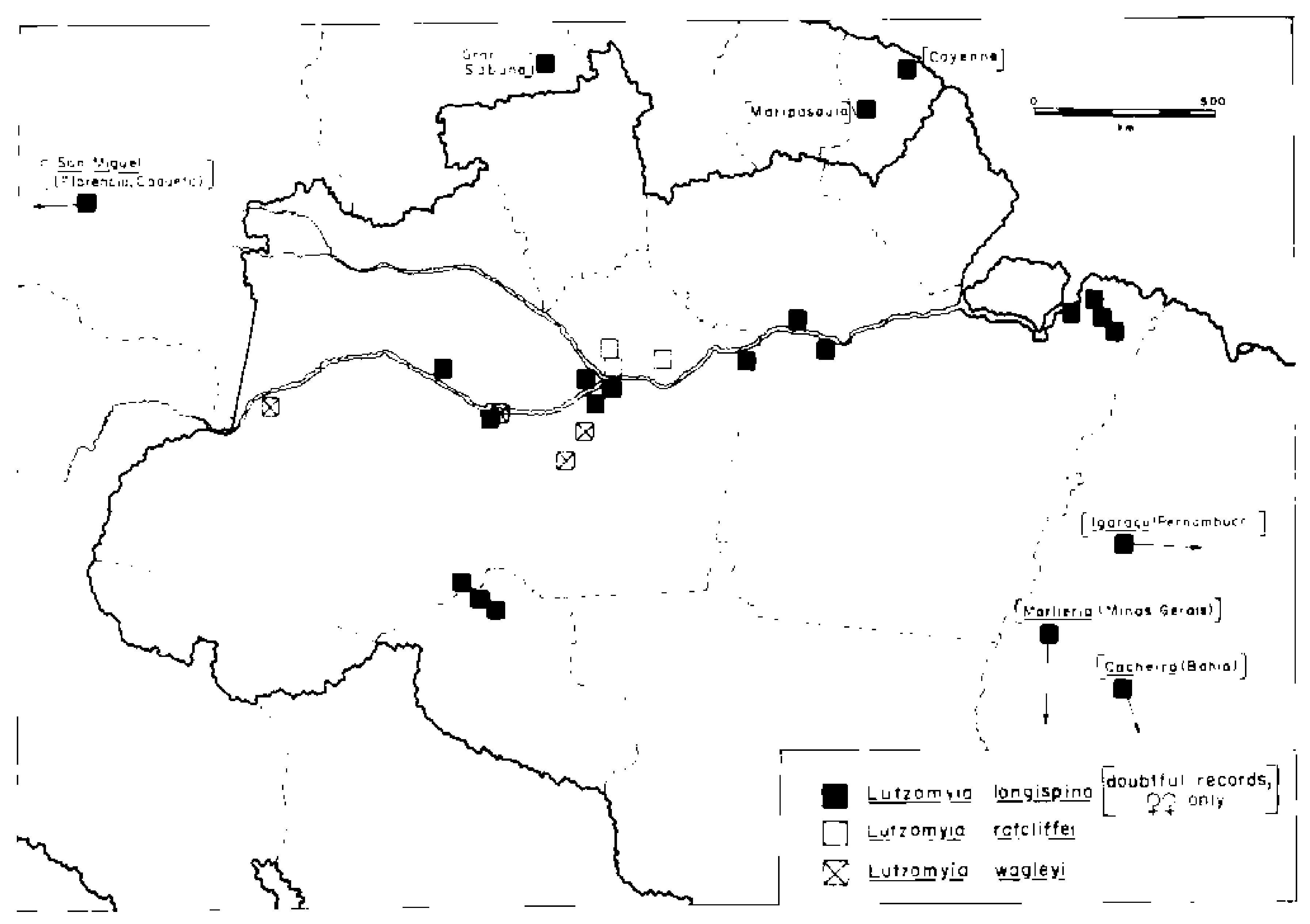

Map. 3 - Known geographical distribution of Lutzomyia longispina, L. ratcliffei and L. wagleyi.

clypeus $0.33(0.33-0.36)$ width $0.32(0.31-0.33)$. Eyes separated by $0.126(0.11-0.13)$ or by a distance equal to $7.0(7.0-7.1)$ facet diameters. Interocular suture present at the sides. Flagellomere 1, $0.23(0.26-0.27)$; ascoids simple. present on all flagellomeres except last two; tips of those on Il ending before end of flagellomere. Labrum $0.19(0.17-0.19)$ long. Length of palpal segments; 1. $0.034(0.033-0.038) ; 2,0.098(0.093-0.11) ; 3,0.14$ $(0.13-0.14) ; 4.0 .1](0.091-0.11) ; 5,0.33(0.21-0.26)$; palpal sensillae present on the distal part of palp two and on the middle $1 / 3$ of palp 3 . Cibarium devoid of dotlike remnants of teeth, cibarial arch incomplete, no pigment patch present. Pharynx unarmed. Thorax $0.48(0.47-0.50)$ long. Pleura with $20(17-20)$ upper and $3(3-4)$ lower mesanepisternal setae. Length of wing vein sections: alpha $(0.49-0.54)$; beta $(0.17 \cdot 0.20)$; delta (0.030-0.055): gamma (0.26-0.29). Length of femora, tibiae and basitarsi: foreleg, 0.78 $(0.78-0.82), 0.86(0.85-0.92) .0 .48(0.46-0.48)$; midleg, $0.80(0.75-0.80), 1.04$ (1.041.11). $0.55(0.52-0.56)$ : hindleg. $0.86(0.85-0.88), 1.28(1.26-1.33), 0.65(0.61-0.65)$. Genitalia. Style $0.22(0.21-0.22)$ long with 4 major spines inserted on the distal $2 / 3$ of segment: subterminal seta present. Coxite $0.31(0.31-0.36)$ long without a persistent tuft of hairs but with a row of long hairs along the inner surface. Paramere bifurcate with a dorsal arm bearing long hairs on its dorsal surface, the distal part of the dorsal arm ending in a short tubular hairless projection bearing 3-6 hairs at the tip, and a thick subcylindrical basal arm bearing hairs on its dorsal surface. Aedeagus subtriangular with an acute tip, well pigmented. Genital pump $0.16(0.16-0.18)$ long, each filament $0.43(0.39-0.44)$ long or ca. $2.63(2.37-2.67) \mathrm{X}$ length of pump. Lateral lobe $0.44(0.44)$ long. Cercus subtriangular as shown.

\section{Female. Unknown.}

Discussion. Of the hundreds of thousands of sand flies examined from the Manaus area (mostly from CDC light (raps), fewer than 50 Lutzomyia ratcliffei have been taken. This species is sympatric with $L$. trichopyga in most of the localities where the former has been captured and with $L$. dasipodogeton at the Km 133 (Highway AM-010) 

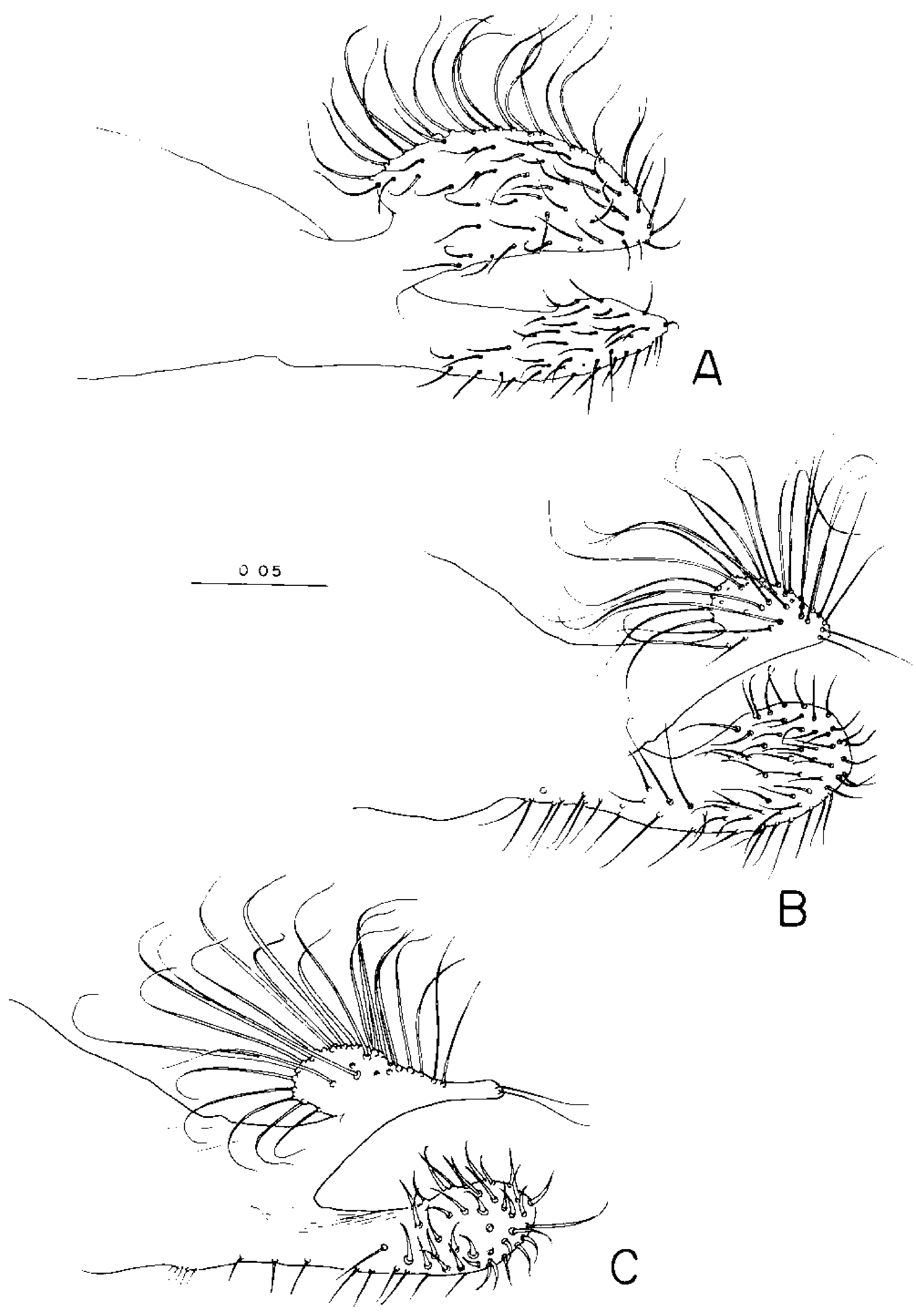

Fig. 4 - Parameres of : A, Lutzomyia wagleyi ; B, L. longispina and C, L. rat cliffei. 

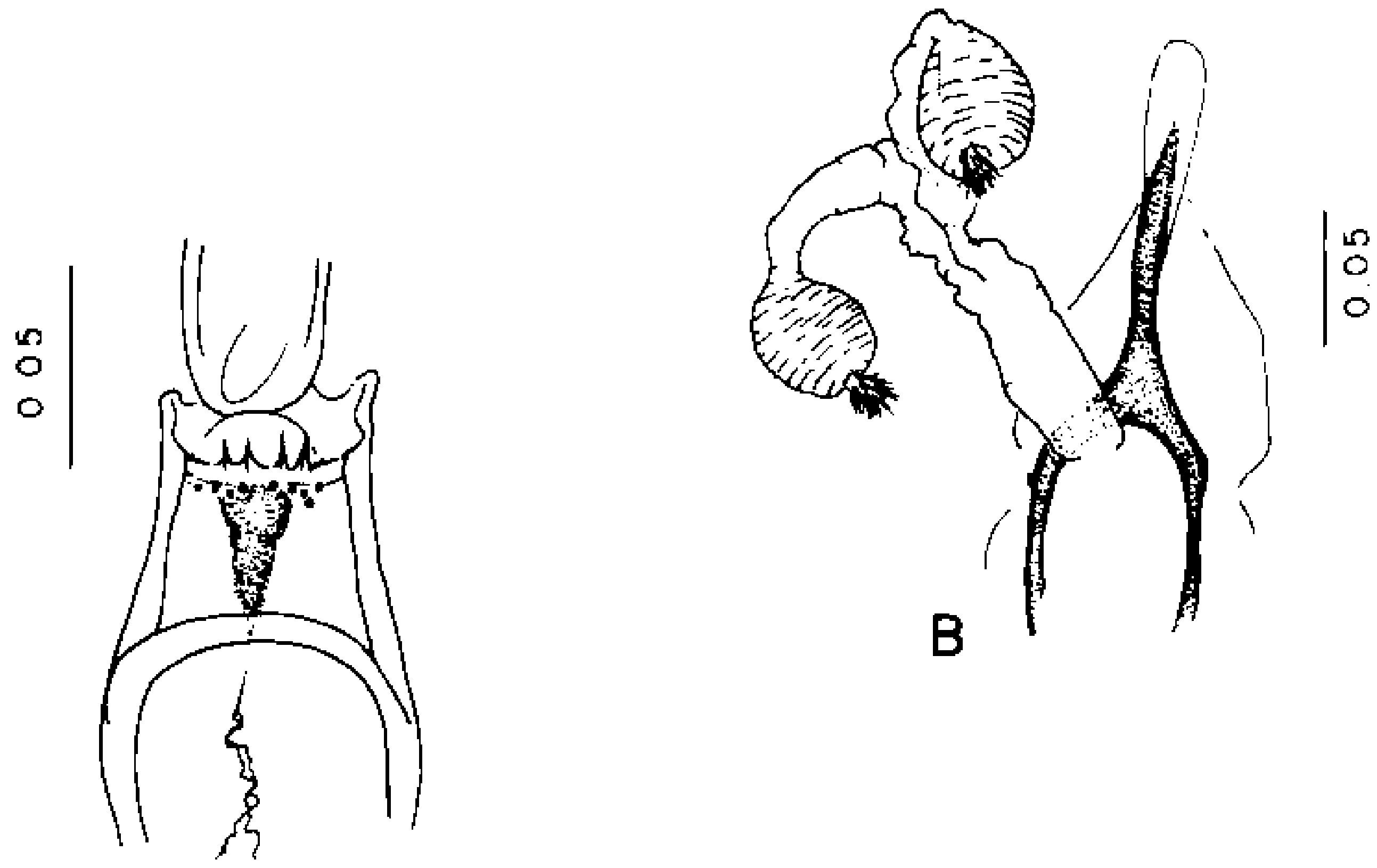

A

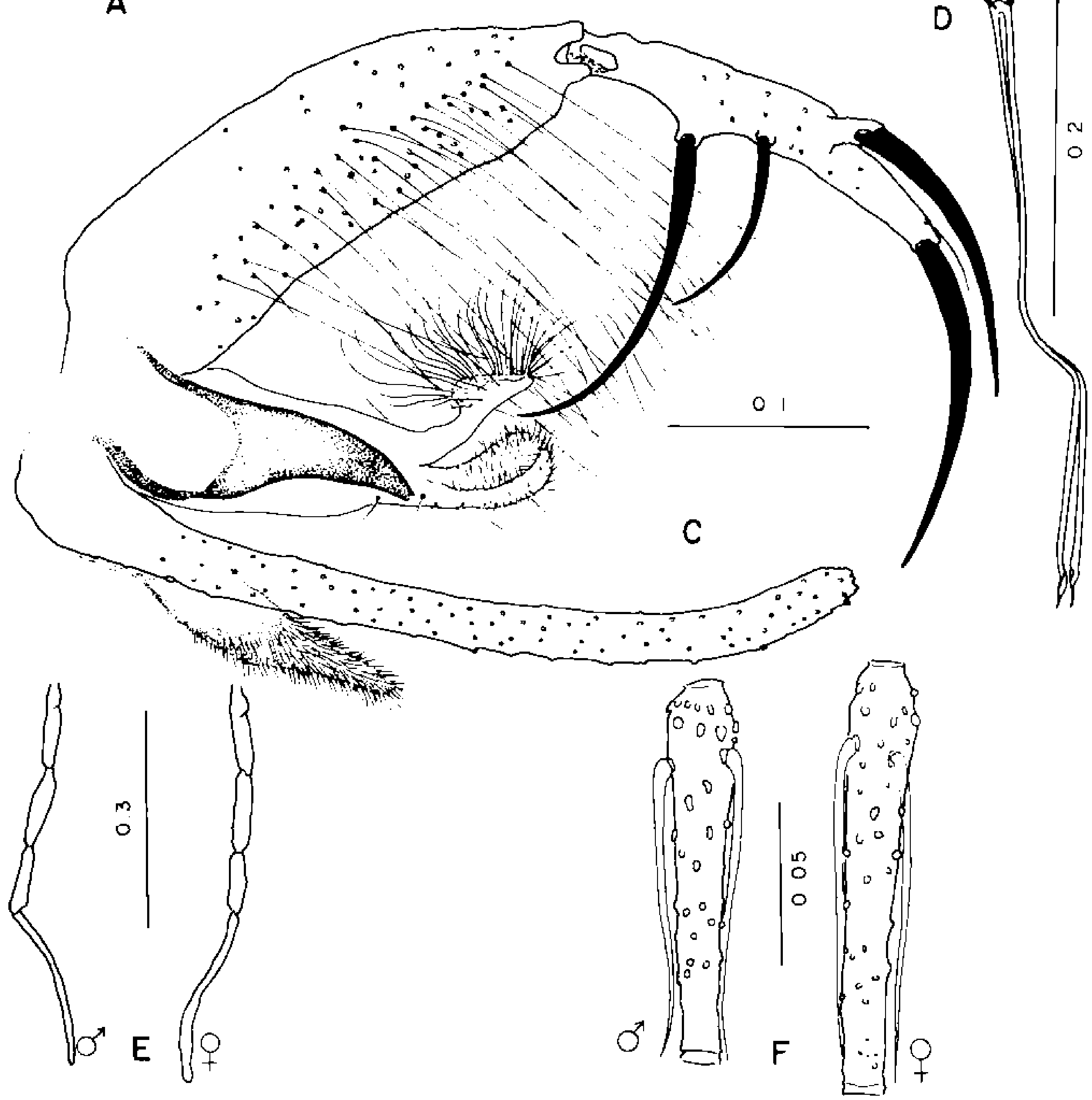

Fig. 5 - Lutzomyia longispina: A, 9 cibarium; B, spermathecae with ducts; C, ơ genitalia; D, genital pump with filaments; $E$, palps; $F$, flagellomere II. 
locality. All of the females collected in all the study sites represent $L$. trichopyga, the males of which are found much more frequently than $L$. ratcliffei. We have not found any females, which we believe to be very close to the females of $L$. longispina and $L$. wagleyi.

The male of this species is very close to those of $L$. longispina and $L$. wagleyi but can be separated as previously discussed under L. longispina (Discussion).

L. ratcliffei was taken in low numbers throughout the year in CDC light traps set at 1 and 15 meters above the forest floor in "terra firme" forests, as well as in emergence traps set on "terra firme" forest floors.

Male Holotype, Brazil, Amazonas, Parque das Laranjeiras (Manaus), CDC-Contro B-1-1 25/06/1981. Arias et. al. coll. 7 ơ paratypes, Brazil, Amazonas, Reserva Ducke, Km 26, Rodovia Torquato Tapajós (Highway AM-010) eclosion trap, various dates, 1978. J. Arias, R. Freitas \& J. Vidal coll. 4 do paratypes same as above but taken in CDC miniature light traps baited with dry ice and placed 1 meter above the forest floor, various dates $1977 \& 1978 ; 19$ o 8 paratypes, same as above, but taken at $15 \mathrm{mts}$ above forest floor, in the tree canopy, various dates 1977 \& 1978. 1 o paratype Km 133 (Fazendas Unidas) of High way AM-010, CDC light trap at 1 meter, 5/3/79 J. Arias, R. Freitas \& J. Vidal coll. 1 of paratype Cidade Nova (Manaus) animal (Armadillo) burrow, 15/8/82. R.N.L. Santos coll. 3 of paratype Parque das Laranjeiras (Manaus) CDC light trap at 1 meter 6 to $8 / 81.600$ paratypes, same information but at 15 meters above the forest floor, Arias et al. coll. Holotype and two paratypes to be deposited in the Entomological collections of the Instituto Nacional de Pesquisas da Amazonia. Other paratypes to be deposited in Brazil: Museu Paraense Emilio Goeldi, Belém, Pará; Museu da Universidade de São Paulo, São Paulo; Universidade Federal de Minas Gerais, Belo Horizonte, Minas Gerais and Instituto Oswaldo Cruz, Rio de Janeiro. Other paratypes to be deposited in: United States Natural History Museum, Washington, D.C.; University of Florida sand-fly Collection, Gainesville, Florida; British Museum of Natural History, London. England.

Material Examined. 39 of from Amazonas State as cited above as type material.

This species is named in honor of Dr. Brett C. Ratcliffe who has done much work on the insects of the Amazon Basin, particularly in the Reserva Ducke (INPA) where most of the specimens were taken.

\section{Lutzomyia rondoniensis Martins, Falcão \& da Silva, 1965}

(Fig. 7; map 2)

Lutzomyia rondoniensis Martins, Falcão \& Silva, 1965 ( $\$$ described from Abunã, Rondônia, Brazil). Forattini, 1973: 318 et seq. (gen. review, figs.). Ramirez-Perez et al., 1976:602 (cf. to conviti). Martins et al., 1978: 114 (listed. distribution).

Distribution: Brazil - Amazonas State: Highway BR-319 (Manaus-Porto Velho) $275 \mathrm{kms}$. of Manaus, 8 o CDC light trap, J. Arias et al. coll. Rondonia State: Abunã, 1 to armadillo burrow (Martins et al. 1965: 14). BR-319 (Manaus - Porto Velho) Km 866, various $\$ 0$ CDC light traps at various heights, various dates 1979-1982 (Biancardi et al., 1982 and J.R. Arias et al., coll). BR-364 (Porto Velho - Vilhena) Kms. 8 \& 48 (Cachoeira do Samuel), Ariquemes \& Vilhena, same information (Ibid).

Material Examined. Over 75 of from all the localities cited above as distribution records except for Guajará Mirim. Specimens were collected throughout year in CDC light traps placed at one and 6 meters above the forest floor.

Discussion. At present Lutzomyia rondoniensis has been taken only in the State of Rondônia and to a lesser extent along the BR-319 Highway in Amazonas State. The $q$ of this species has not yet been described; Trichopygomyia females collected in association 


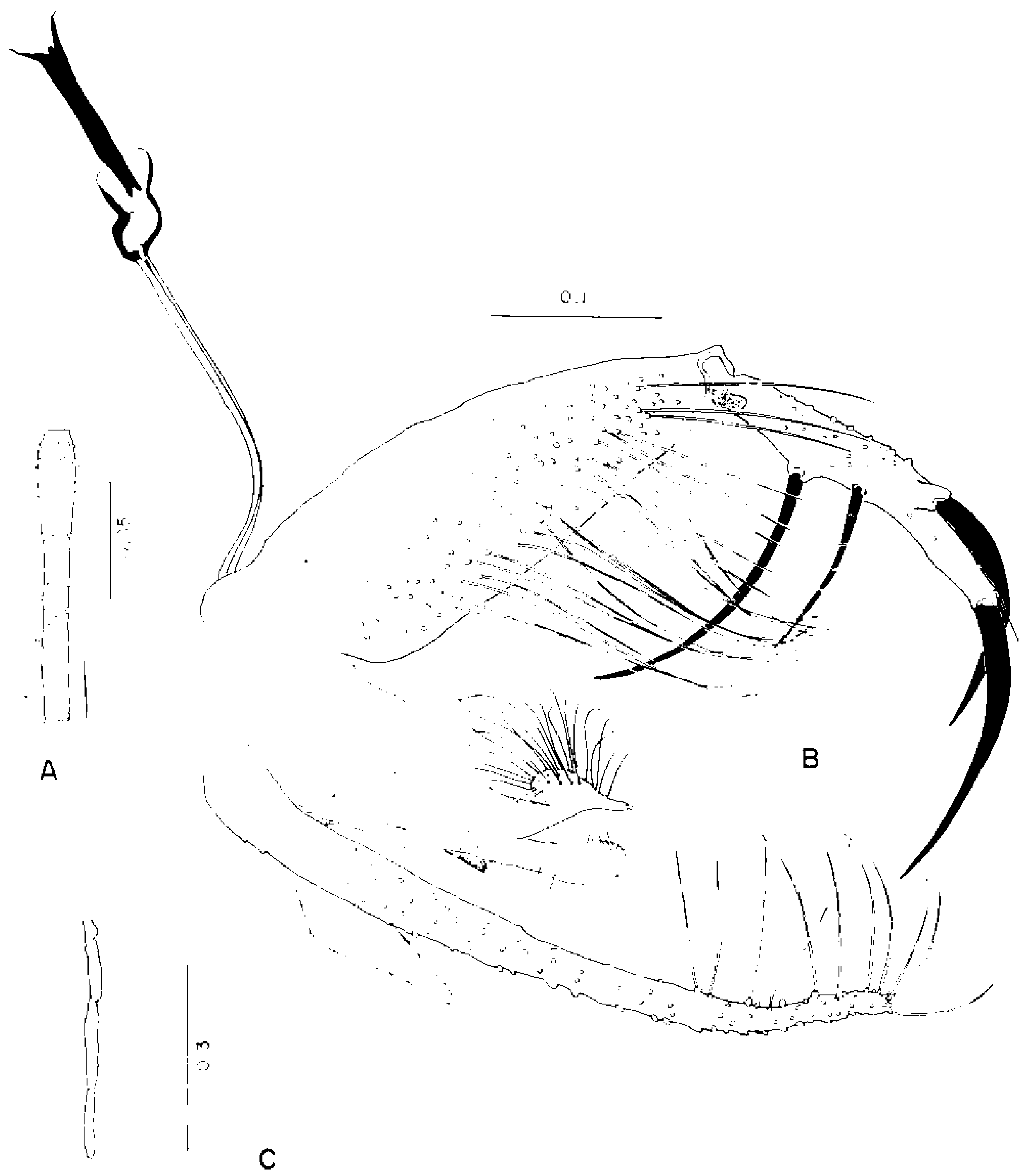

Fig. 6 - Lutzomyia ratcliffei n.sp.: A, tlagellomere II: B. O genitalia; C, palp.

with the males could be $L$. dasipodogeton. L. longispina or L. wagleyi, all of which are sympat ric.

The males of $L$. rondoniensis and $L$. conviti are very similar, but can be separated by the shape of the aedegus (Figs. $1 \& 7$ ).

Specimens of this species show a wide variation in size, those from the Vilhena area have larger measurements than males from Km 275 (BR-319). The similarity of all the structures. particularly the paramere, indicate that all the specimens are conspecific. 


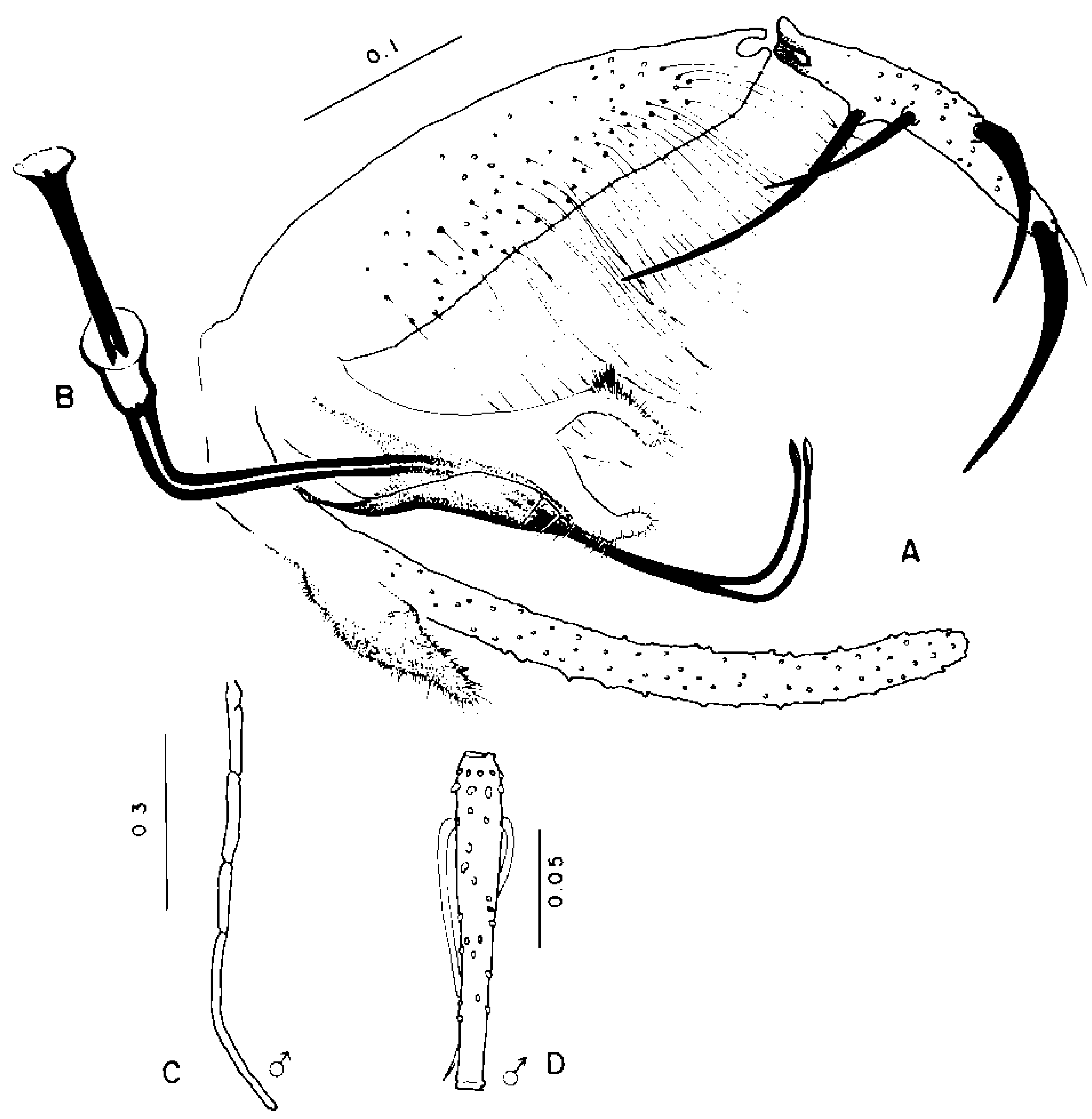

Fig. 7 - Lutzomyia rondoniensis: A, of genitalia; B, genital pump with filaments; C, palp; D, flagellomere II.

\section{Lutzomyia trichopyga (Floch \& Abonnenc, 1945)}

(Fig. 8; map 2)

Phlebotomus trichopygus Floch \& Abonnenc, 1945:2-4, 11-12 (6 9 described from Crique Anguille, French Guiana). Floch \& Abonnenc, 1952:92.94 ( $\delta \&$ described). Fairchild \& Hertig, 1952:518 (cf. to triramulus). Fairchild, 1955:195 (classified).

Lutzomyia trichopyga: Barretto, 1962:98 (classified). Theodor, 1965:190 (classified). Martins et al., 1965:14 (cf. to rondoniensis). Forattini, 1971:102 (classified). Forattini. 1973:320 et seq. (gen. review, figs.). Lewis, 1975:502 et seq. (mouthpart morph.). Ramirez-Perez et al., 1976:602 (cf. to conviti). Martins et al., 1978:113-1 14 (listed, distribution).

Distribution. Brazil - Amapa Federal Territory: Teresinha, $4 \delta^{\circ} \delta$, to light (Forattini, 1960:477). Amazonas State: Parque das Laranjeiras and AM-010 (Manaus Itacoatiara) $\mathrm{Kms} 26,30,133 \& 246$, $80 \% 9$ common in CDC light traps, various dates 
1975-1982 (J.R. Arias et al. coll.). Pará State: near Monte Dourado, $069 \%$ abundant in armadillo burrows, common in CDC light traps, various dates 1978.1981 (P.D. Ready \& R. Lainson coll.); near Porto Trombetas do $\$ q$ abundant in armadillo burrows, April 1980 (P.D. Ready \& R.P. Lane coll.). French Guiana - Crique Anguille, 12 of 1 \% burrow (Floch \& Abonnenc, 1945:4); near Cayenne, 1 o Léger et al., 1977:218); Maripasoula, $20 \delta 3 \% 9$ (Ibid); Haut Oyapock, 2 ठठ (Ibid).

Material Examined. Many of $\$ \%$ from the regions of Manaus, Monte Dourado $\left(0^{\circ} 47^{\prime} \mathrm{S}, 52^{\circ} 40^{\prime} \mathrm{W}\right)$ and Porto Trombetas $\left(1^{\circ} 27^{\prime} \mathrm{S}, 56^{\circ} 24^{\prime} \mathrm{W}\right)$. Sexes associated by laboratory-rearing of individual egg broods (10) laid by naturally engorged $\$+$ caught in an armadillo burrow near Monte Dourado, August 1979.

Discussion. Lutzomyia trichopyga is known to be sympatric with $L$. dasipodogeton and $L$. ratcliffei near Manaus and sympatric with $L$. dasipodogeton near Monte Dourado. In both areas, it is the most commonly captured species of Trichopygomyia. Floch \& Abonnenc (1952:94) refer to the female as having six strong horizontal teeth in the cibarium. This accords with their figure (27) which is a reproduction of that (Fig. 2) given with the original description of the type female (Floch \& Abonnenc, 1945:12). However, the text of the original description refers to four strong horizontal teeth. Brazilian specimens always have but four horizontal teeth. Unfortunately, we have not

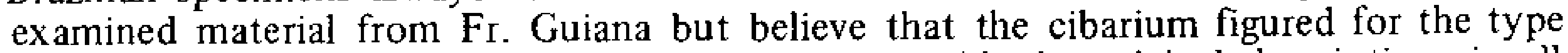
female is aberrant, since Brazilian material agrees with the original descriptions in all other characters.

\section{Lutzomyia triramula (Fairchild \& Hertig, 1952) (Fig. 9)}

Phlebotomus triramulus Fairchild \& Hertig, 1952:517.519 ( $\&$ described from Rio del Medio and Cerro Jefe respectively, Panama).

Lutzomyia triramula see Young 1979:123 (full references). Martins et al., 1978:11 (listed, distribution).

Distribution. Belize - various localities: $51 \delta \delta, 23 \% q$ light trap \& oil trap (Williams, 1970). Colombia - Antioquia: Rio Anori $108 \delta \delta, 9499$ light \& flight traps various dates, 1970 (Young, 1979). Choco: Alto Curiche, 4 8', 1999 July - Nov. 1967 (Ibid.); Curiche 111 60, 237 \$\% light, malaise \& Shannon traps various dates 1967, (Ibid.); Teresita 1 o tree trunk June 1967; 1 o light trap Oct. 1967 (Ibid.). Santander: S. Vicente do Chucuri 2 ठठ in tree hollow associated with bats 17-8-1944 (Sherlock, 1962). Valle: Taparalito (Rio Raposo) 22 of 23 \%q light baited Shannon trap, from 1959-1969 (Barreto, 1969); 25K E of Buenaventura 1 d, $2 \% q$ tree trunk 1973 (Young 1979); same locality 5 ot, $13 \% 9$ light trap 1973 (Ibid). Panama - Canal Zone: Barro Colorado Is., Camp Chagres, Empire Range, Gatum, Howard, Kobe, Limbo Field Station, Mojinga, Swamp \& Sherman, $1000+\delta \delta^{\circ} 1000+\wp \wp$ in tree butress, light traps, Shannon traps, tree hollows \& primarily animal burrows, various dates $1944-1973$ (Chaniotis \& Correa, 1974: Chaniotis et al., 1971, 1972; Fairchild \& Hertig, 1952; Rutledge et al., 1975, 1976). Colon: Cacique, Cerro Santa Rita, Palenque, Rio del Medio, $\delta 0 \$ \uparrow$ light traps, tree bases, and mostly in animal burrows (Fairchild \& Hertig, 1952). Panama: Camp Chorrera, Campana, Cerro Azul, La Victoria (Near Pacora) same information (Fairchild \& Hertig, 1952: Herrer \& Christensen, 1976).

Material Examined. $2 \$ 8$ \& 2 \% , Colombia, Antioquia, Rio Anori, $24 \mathrm{Km}$ SW of Saragaza, light trap, all on 22 Sept. 1970, except one of on 15 Sept., 1970, D.G. Young coll. 


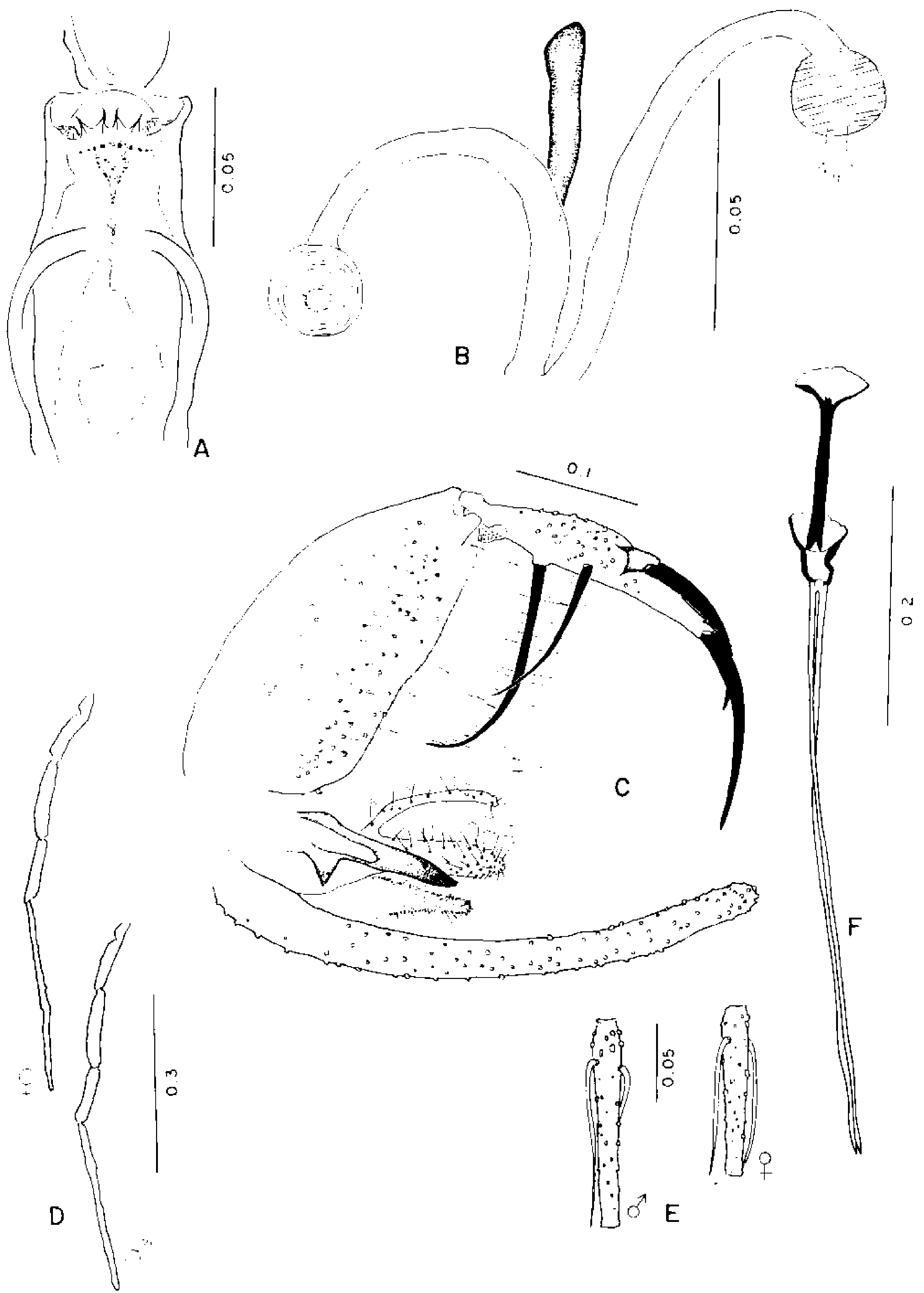

lig. 8 l.utzomvia trichopyga: A. 9 ciharium: B, spermathecae with ducts: C. $\sigma$ genitalia: D, palps: 1. thagellomere $11 ; H$, genital pump with filaments. 


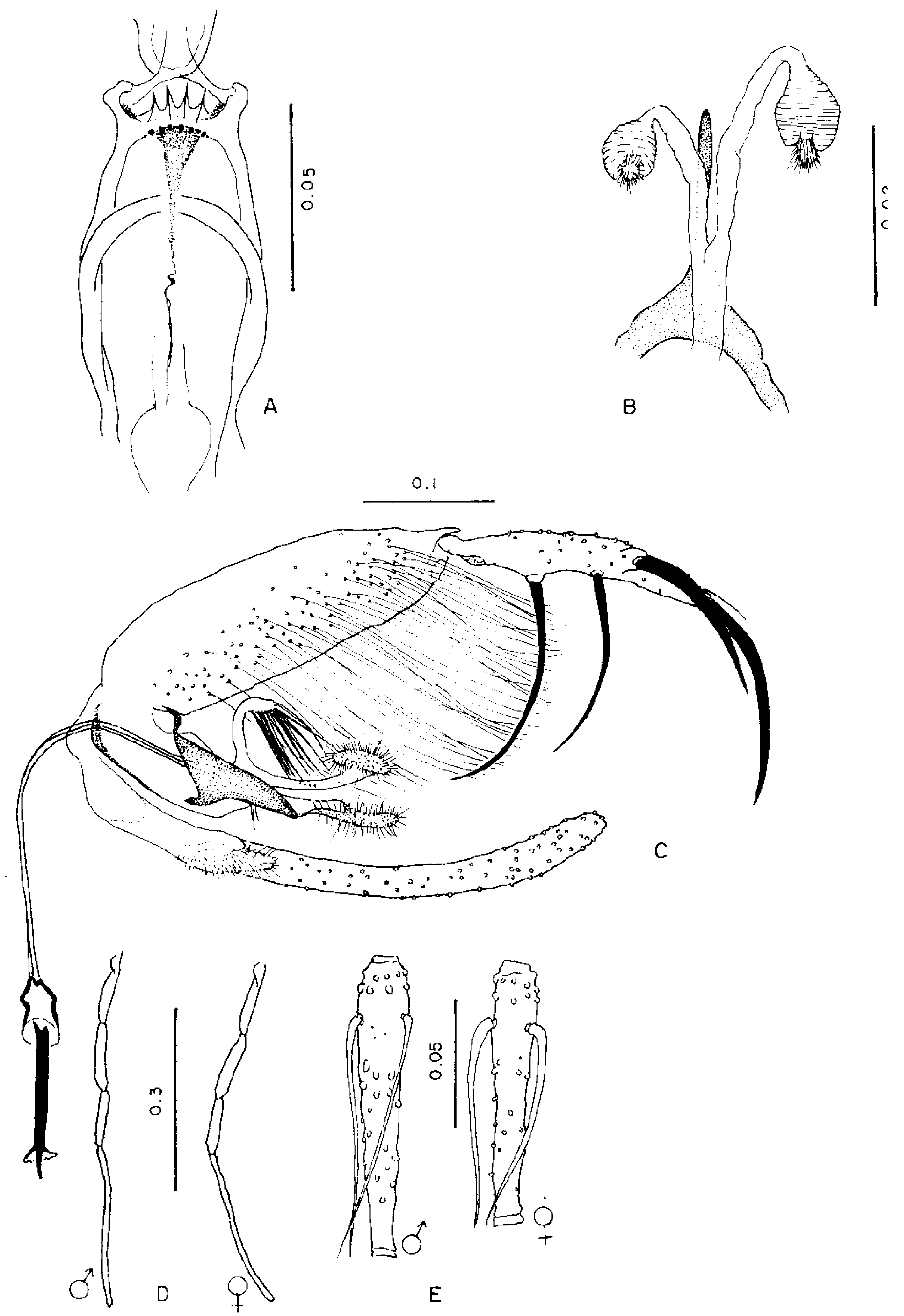

Fig. 9 -Lutzomvia triramula: A, 9 cibarium; B, spermathecae with ducts; C, of genitalia; D, palps; fi. flagellomere il. 
Discussion. This is the only species in the subgenus that is found in Central America. Young (1979) found structural variations in parameres of specimens from different localities but considered it to be intraspecific variation.

\section{Lutzomyia waglevi (Causey \& Damasceno, 1945)}

(Fig. 4, 10; map 3)

Flebotomus wagleyi Causey \& Damasceno, 1945:25-29 ( $₫$ holoty pe described from São Paulo de Olivença, Amazonas).

Phlebotomus wagleyi: Floch \& Abonnenc, 1952:33 (o, keyed). Fairchild \& Hertig, 1952:518 (cf. to triramulus). Fairchild, 1955:195 (classified).

Lutzomyia wagleyi: Barretto, 1962:98 (classified). Martins et al., 1965:14 (cf. to rondoniensis). Theodor, 1965:190 (classified). Forattini, 1971:102 (classified). Forattini, 1973:325 et seq. (gen. review, figs.). Martins et al., 1978:115 (listed, distribution). Morales \& Minter 1981:101 ( $\%$ described).

Distribution. Brazil - Amazonas State: Coari, 169 ठt in armadillo burrows. various dates 194245 (Damasceno et al. .1949:834, 842); São Paulo de Olivença, 1,069 ơ , same information (Ibid.); BR-319 (Manaus - Porto Velho) Km 275, 2 ơ May 1978 and 1 o July 1981 in CDC light traps $6 \mathrm{~m}$ above forest floor (J.R. Arias et al., coll.); BR-319, Km 400, 1 o as before, October 1978 (Ibid). Colombia - Caqueta State: Araracuara 2 む‡, 699 light trap, 1-20 July 1977 (Morales \& Minter, 1981:101).

$1978 \& 1981$.

Material Examined. 4 8ठ BR-319 (Manaus - Porto Velho) $275 \mathrm{Km}$ of Manaus,

\section{IDENTIFICATION}

There are many Lutzomyia species whose males have a style which bears four major spines inserted at different levels and a small subterminal seta. Trichopygomyia species, however, are unique, in combining this character with: a bifurcate or trifurcate paramere, and a coxite which bears a ventral fringe of long hairs but no discrete patch of setae (and no tubercle). The spermathecae are characteristic for the subgenus. Morphometric measurements of the various species show a great deal of overlap as can be seen in Table I. Species differentiation by these characters is unreliable.

\section{TABLE I}

Measurements (in mm) of various structures of males of the subgenus Trychopygomyia

\begin{tabular}{|c|c|c|c|c|c|c|}
\hline \multirow{2}{*}{ Species } & \multirow{2}{*}{$\begin{array}{c}\text { lst } \\
\text { flagellomere }\end{array}$} & \multirow{2}{*}{$\begin{array}{l}\text { Lateral } \\
\text { lobe }\end{array}$} & \multirow{2}{*}{ Coxite } & \multirow{2}{*}{$\begin{array}{l}\text { Sperm } \\
\text { pump }\end{array}$} & \multirow{2}{*}{$\begin{array}{l}\text { Genital } \\
\text { filaments }\end{array}$} & \multirow{2}{*}{$\frac{\text { Genital filaments }}{\text { Sperm pump }}$} \\
\hline & & & & & & \\
\hline Lutzomyia conviti & 0.26 & 0.45 & 0.36 & 0.16 & 0.49 & 3.0 \\
\hline L. dasipodoge ton & $0.25-0.28$ & $0.46-0.48$ & $0.37-0.39$ & $0.17-0.18$ & $0.47 \times 0.51$ & 2.8 \\
\hline L. elegans & $0.26-0.27$ & $0.45-0.47$ & $0.34-0.36$ & $0.16-0.17$ & $0.43-0.46$ & $2.6-2.8$ \\
\hline L. longispina & $0.22-0.28$ & $0.43-0.47$ & $0.29-0.35$ & $0.16-0.19$ & $0.41-0.47$ & $2.2-2.7$ \\
\hline L. ratcliffej & $0.23-0.27$ & 0.44 & $0.31+0.36$ & $0.16-0.18$ & $0.39-0.44$ & $2.3-2.7$ \\
\hline L. rondoniensis & $0.23-0.33$ & $0.44-0.47$ & $0.31-0.35$ & $0.16-0.17$ & $0.44-0.51$ & $2.7-3.1$ \\
\hline L. trichopyga & $0.24-0.28$ & $0.42-0.45$ & $0.30-0.33$ & $0.15-0.16$ & $0.42-0.45$ & $2.7-3.0$ \\
\hline L. triramula & $0.23-0.24$ & $0.39-0.40$ & $0.29-0.34$ & $0.14-0.15$ & $0.40-0.41$ & $2.7-2.9$ \\
\hline L. wagleyi & $0.23-0.26$ & $0.44-0.46$ & $0.32-0.34$ & $0.16-0.19$ & $0.39 \cdot 0.49$ & $2.4-3.0$ \\
\hline
\end{tabular}




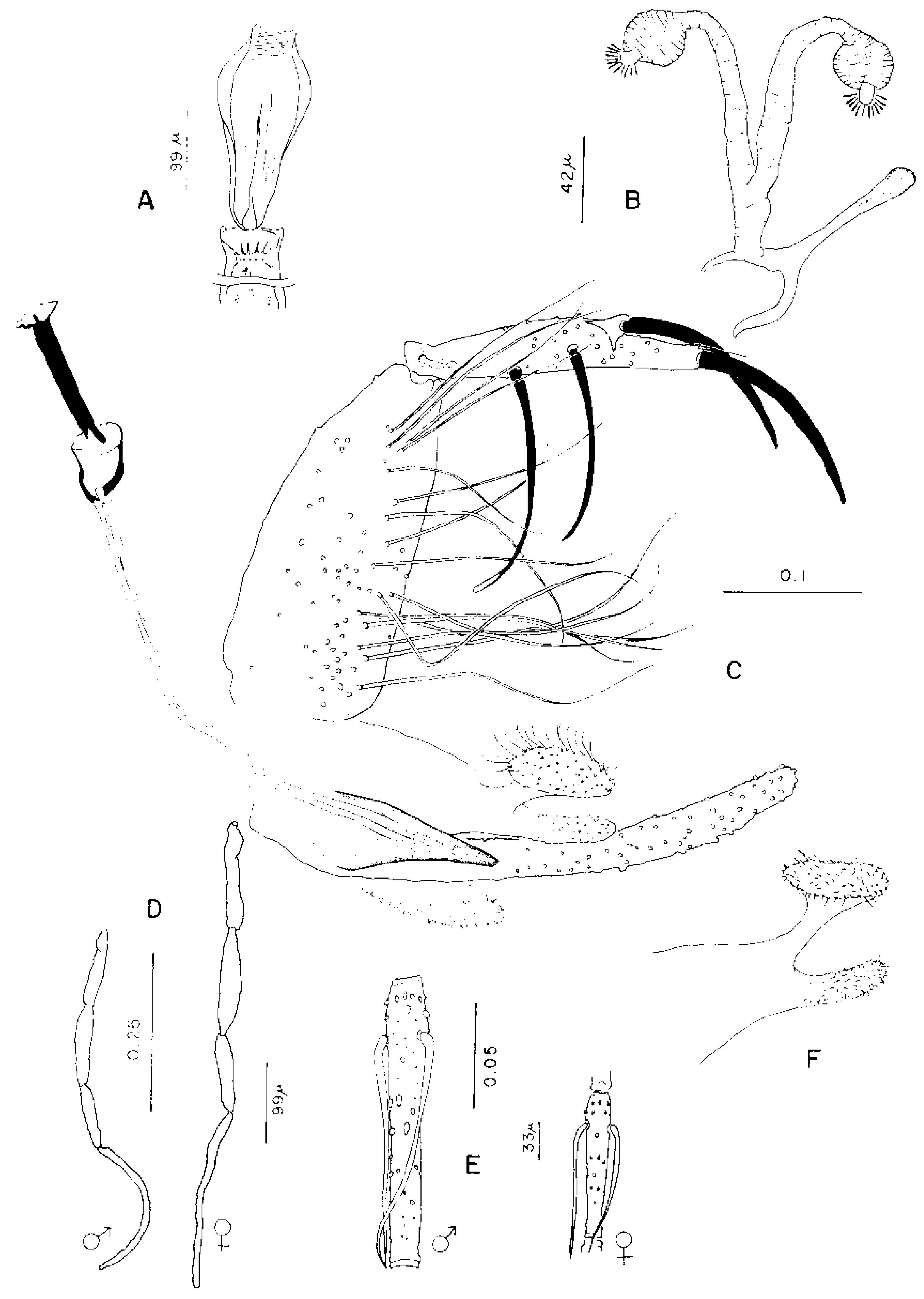

Fig. 10 - Lutzomyia wagleyi: A, $\supsetneq$ cibarium; B, spermathecac with ducts; C, of genitalia; D, palps; F, flagellomere II $; \mathbf{F}$, paramere (all ${ }^{+}$structures after Morales $\&$ Min ter, 1981). 


\section{KEY TO THE MALES OF TRICHOPYGOMYIA}

1. Paramere trifurcate . . . . . . . . . . . . . . . . . 2

Paramere bifurcate. . . . . . . . . . . . . . . . 3

2. Medial lobe of paramere subequal to the basal lobe ........ L. triramula

(Fig. 9)

Medial lobe of paramere reduced to a small protuberance, smaller than the basal lobe.

\section{L. elegans}

(Fig. 3)

3. Aedeagus with large dorsal, reclined, lobular projection; dorsal arm of paramere less than half length of ventral arm.

\section{L. dasipodogeton}

(Fig. 2)

Aedeagus usually without dorsal projection (if present, only a mound); dorsal arm of paramere subequal in length to ventral

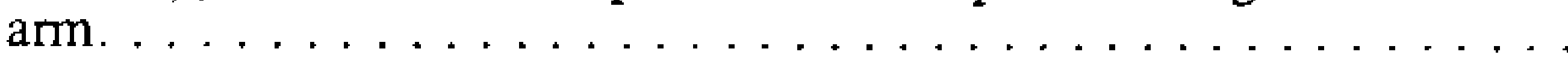

4. Paramere wrench shaped (Figs. 1,7$) \ldots \ldots \ldots \ldots \ldots \ldots$

Paramere otherwise

4

6

5. Dorsal mound on aedeagus present

L. conviti

(Fig. 1)

No dorsal mound on aedeagus

\section{L. rondoniensis}

(Fig. 7)

6. Dorsal arm of paramere slender, uniform in size throughout

\section{L. trichopyga}

(Fig. 8)

Dorsal arm of paramere enlarged distally . . . . . . . . . . 7

7. Dorsal arm of paramere not markedly tapering distally

L. wagleyi

(Figs. 4 \& 10)

Dorsal arm of paramere markedly tapering distally.

8. Distal end of dorsal arm of paramere tubular with a few fine hairs protruding from tip.

\section{L. ratcliffei n. sp.} (Figs. $4 \& 6$ )

Distal end of dorsal arm of paramere not tubular, setae on tip uniformly distributed.

\section{L. longispina}

(Figs. 4 \& 5)

\section{KEY TO THE FEMALES OF TRICHOPYGOMYIA}

1. Length of individual sperm duct not more than two times that of common duct. . . . . . . . . . . . . . . . . . .

Length of individual sperm duct at least four times that of common duct . . . . . . . . . . . . . . . . . . . . .

2. Length of common sperm duct less than two times the width of the spermatheca

\section{L. longispina (Fig. 5) \\ L. wagleyi}

(Fig. 10) 
Length of common sperm duct more than twice the width of the spermatheca . . . . . . . . . . . . . . .

L. triramula

(Fig. 9)

3. Common sperm duct conspicuous, at least $1 / 4$ the length of the individual duct

\section{L. elegans \\ (Fig. 3)}

Common sperm duct inconspicuous or very short $\ldots \ldots \ldots \ldots$

4. Length of individual sperm duct not more than three times the length of the spermatheca.

Length of individual sperm duct about five times the length of the spermatheca . . . . . . . . . . . . . . . .

5. Cibarial arch complete

L. dasipodogeton (Fig. 2)

\section{5}

L. conviti

(Fig. 1)

Cibarial arch conspicuous only at sides

L. trichopyga

(Fig. 8)

All species are generally light brown in colour, but the head and mesonotum are usually perceptibly darker than other parts.

The females of $L$. ratcliffei, at present unknown, probably have spermathecae very similar to those of $L$. longispina. Similarly (based on male likeness), the spermathecae of $L$. rondoniensis would be expected to have long individual sperm ducts and an inconspicuous common sperm duct, like those of $L$. conviti.

\section{Ecology}

Trichopygomyia species seem to share the same broad ecological niche, all being largely sylvatic, terrestrial and associated with armadillos and other burrowing mammals. The type descriptions of seven species are based on material caught in armadillo burrows (6 species) or a "burrow" (L. trichopyga); the exceptions are L. ratcliffei, of which little is known, and $L$. triramula, paraty pes of which were caught in animal burrows. Excepting the less well known species, all have been taken (frequently) in light traps and from tree bases, but the largest populations have been encountered in armadillo burrows and, to a lesser extent, in rodent burrows (Cuniculus spp.) (Damasceno et al., 1949; Fairchild \& Hertig, 1952; Ready \& Lainson, unpublished observations). Christensen \& Vasquez (1982) found both sexes of $L$. triramula to be common on tree bases above animal burrows in Panama; the host of $57 / 75$ blood-engorged females of this species was identified as armadillo. In Pará State, Brazil, the armadillo Dasypus novemcinctus is commonly infected by a form of Leishmania braziliensis s.l. (Lainson et al., 1979). Infected armadillos were encountered in a "terra firme" forest near Monte Dourado, and L. trichopyga was found to be abundant in occupied burrows (Lainson et al., 1979; Ready \& Lainson, unpublished observations). Trichopygomyia species have yet to be associated with different armadillo species, but such a means of isolation seems likely. It is interesting to note that $L$. longispina and $L$. wagleyi have been taken most frequently in lowland areas were soils are generally moist, whereas $L$. dasipodogeton is as common in highland areas. 


\section{RESUMO}

O subgênero Trichopygomyia Barretto, 1962 do flebótomo Lutzomyia spp. França, 1924 é revisto e corresponde às espécies incomuns do grupo longispina de Theodor (1965). E também descrita Lutzomyia (Trichopygomyia) ratcliffei n.sp. da Bacia Amazônica. Figuras, chaves, mapas de distribuiçāo e notas sobre ecologia são apresentados para todas as formas conhecidas. As espécies mais conhecidas são freqüentemente encontradas em tocas de tatu e, portanto, podem ser vetores de Leishmania.

\section{ACKNOWLEDGEMENTS}

We are very grateful to Dr. David Young for his comments and suggestions on this manuscript and to Srs. João F. Vidal, Iorlando R. Barata, Raimundo L. Santos, Manoel C.M. Souza, Francisco L. Santos and Lourival Castro for their assistance in the field and laboratory. Artemio Coelho da Silva is acknowledged for the drawings.

\section{REFERENCES}

BARRETO, P., 1969. Artropodos hematófagos del Río Raposo, Valle, Colombia. IV. Psychodidae. Caldasia $10: 459472$.

BARRETTO, M.P., 1962. Novos subgêneros de Lutzomyia França, 1924 (Diptera, Psychodidae, subfamilia Phlebotominae). Rev. Inst. Med. trop. S. Paulo 4 :91-100.

BIANCARDI, C.B.; ARIAS, J.R.; FREITAS, R.A. \& CASTELLON, E.B., 1982. The known geographical distribution of sand flies in the state of Rondonia, Brazil (Diptera:Psichodidae). Acta Amazon, $12: 167-179$.

CASTRO, G.M.O., 1939. Hábitos de alguns flebótomos brasileiros. Jornal do Commécio, Rio de Janeiro, Ano $112, \mathrm{n}$. 81 , p. 4.

CAUSEY, O.R. \& DAMASCENO, R.G., 1945. Estudo sobre Flebotomus no Vałe Amazônico. Parte II. Descrição de F. dunhami, F. melloi e F. wagleyi. Rev. Serv. Esp. Saúde Públ. $1: 625-640$.

CHANIOTIS, B.N. \& CORREA, M.A., 1974. Comparative flying and biting activity of Panamanian phlebotomine sand flies in natural forest and adjacent open space.J. Med. Ent. $11: 115-116$.

CHANIOTIS, B.N.; TESH, R.B.; CORREA, M.A. \& JOHNSON, K.M., 1972. Diumal resting sites of phlebotomine sand flies in Panamanian tropical forest. J. Med. Ent. $9: 91-98$.

CHANIOTIS, B.N.; NEELY, J.M.; CORREA, M.A.; TESH, R.B. \& JOHNSON, K.M., 1971. Natural population dynamics of phlebotomine sandflies in Panama. J. Med. Ent. $8: 339-352$.

CHRISTENSEN, H.A. \& VASQUEZ, A.M., 1982. The tree buttress biotype: a pathobiocenose of Leishmania braziliensis. Am. J. Trop. Med. Hyg. $31: 243-251$.

DAMASCENO, R.G.; AROUCK, R. \& CAUSEY, O.R., 1949. Estudos sobre Flebotomus no Vale Amazônico. Parte VI. Contribuição ao conhecimento da distribuição geográfica e a incidência por tipo de captura de 64 espécies identificadas. Rev. Serv. Esp. Saúde Públ. 2 :817-842.

FAIRCHILD, G.B., 1955. The relationships and classification of the Phlebotominae (Diptera, Psychodidae). Ann. Ent. Soc. Amer. $48: 182-196$.

FAIRCHILD, G.B. \& HERTIG, M., 1952. Notes on the Phlebotomus of Panama (Diptera: Psychodidae). XI Description of seven new species. Ann. Ent. Soc. Amer. 45 :505-528.

FLOCH, H. \& ABONNENC, E., 1945. Phlebotomus de la Guyane Française (XV) P. elongatus, $P$. sylvicolus, $P$. trichopygus, n.sp. $P$. brasiliensis, $P$. barrettoi et $P$. sp de Crique Anguille. Inst. Pasteur Territ. L. Inini Pub. n? 106 :1-16. 
FLOCH, H. \& ABONNENC, E., 1952. Dipteres phlebotomos de la Guyane et des Antilles Françaises. Faune L'Uniāo Française XVI :1.207.

FORATTINI, O.P., 1971. Sobre a classificaçāo da subfamília Phlebotominae nas Américas (Diptera, Psychodidae) Papeis Avls. Dep. Zool. S. Paulo 24 :93-111.

FORATTINI, O.P., 1973. Entomologia Médica Vol. 4. Psychodidae. Phlebotominae. Leishmanioses. Bartoneloses. Edgard Blucher. S. Paulo. 658 pp.

HANSON, W.J., 1968. The immature stages of the subfamily Phlebotominae in Panama (Diptera, Psychodidae) Ph.D. thesis Univ. Kansas, 104 p. Univ. Microfilis, Arn. Arbor, Mich (Diss. Abstr. 68-17, 390).

HERRER, A. \& CHRISTENSEN, H.A., 1976. Epidemiological patterns of cutaneous leishmaniasis in Panama I. Epidemics among small groups of settlers. Ann. Trop. Med. Parasit. $70: 59-65$.

LAINSON, R.; SHAW, J.J.; WARD, R.D.; READY, P.D. \& NAlFF, R.D., 1979. Leishmaniasis in Brazil: XIIl. Isolation of Leishmonia from armadillos (Dasypus novemcinctus), and observations on the epidemiology of cutaneous leishmaniasis in North Pará State. Trans. Roy. Soc. Trop. Med. Hyg. $73: 239-242$.

LEGGR, N.; ABONNENC, E.; PAJOT, F.X.; KRAMER, R. \& CLAUSTRE, J., 1977. Liste commen tée des Phlébotomes de la Guy ane Française. Cah O.R.S.T.O.M. Sér. Ent. Méd. et Méd. et Parasit. 15 (3) $: 217-232$.

LEWIS, D.J., 1975. Functional morphology of mouthparts in New World phlebotomine sand flies (Diptera: Psych odida) Trans. Roy. Ent. Soc. Lond. 126 :497-532.

LEWIS, D.J.; YOUNG, D.G.; FAIRCHILD, G.B. \& MINTER, D.M., 1977. Proposals for a stable classification of phlebotom ine sand flies (Diptera: Psychodidae) Sys. Ent. $2: 319-332$.

MANGABEIRA, F.O., 1942a. 79 . Contribuição ao estudo dos Flebotomus (Diptera: Psychodidae). Descrição dos machos de 24 novas espécies. Mem. Inst. Oswaldo Cruz $37: 111-218$.

MANGABEIRA, F.O., 1942b. 10 ${ }^{\text {a }}$ Contribuição ao estudo dos Flebotomus (Diptera: Psychodidae). Flebotomus longispinus Mangabeira, 1942. Mem. Inst. Oswaldo Cruz 37 :251-257.

MARTINS, A.V.; FALCÃO, A.L. \& SILVA, J.E., 1963. Notas sobre os flebótomos do território de Roraima, com a descriçāo de três novas espécies (Diptera, Psychodidae) Mem. Inst. Oswaldo Cruz $23: 333-348$.

MARTINS, A.V.; FALCĀO, A.L. \& SILVA, J.E., 1965. Nota sobre os flebótomos do território de Rondônia com a descrição de seis espécies novas (Diptera: Psychodidae). Rev. Bras. Biol. 25 $: 1-20$.

MARTINS, A.V.; LlANOS, B.Z. \& SILVA, J.F., 1976. Estudo sobre os flebótomos do Peru liI. Departamento de Huanuco; Lista das espécjes coletadas e descriçāo de duas espécies novas, Lutzomyia elegans e Lutzomyia ruparupa n.sp. (Diptera: Psychodidae, Phlebotominae) Rev. Bras. Biol. $36: 487494$.

MARTINS, A.V.; WILliaMS, P. \& FALCÃO, A.L., 1978. American Sand Flies (Diptera:Psychodidae, Phlebotominae) Acad. Bras. Ciências, Rio de Janeiro, 195 p.

MARTINS, A.V.: FALCÃO, A.L.; SILVA, J.E. da \& FILHO, R.M., 1983. Nota sobre Lutzomyia (Trychopygomyia) dasypodogeton (Castro, 1939), com a redescrição do macho e da fêmea (Diptera: Psychodid ae, Phlebotominae). Mem. Inst. Oswaldo Cruz 78 (2) :223-230.

MORALES, A. \& MINTER, D.M., 1981. Estudio sobre flebotomineos en Araracuara. Caque tá, Colombia, S.A. Incluyendo la descripcion de Lutzomyia araracuarensis (Diptera, Psychodidae). Biomedica I (3) :94-1 16 .

OSORNO-MESA, E.; MORAES-ALARCON, A.; DE OSORNO, F. \& FERRO-VELA, C., 1972. Phlebotomina da Colombia (Diptera, Psychodidae). IX. Distribucion geografica de espécies de Brumptomyia França \& Parrot, 1921 y Lutzomyia França, 1924 encontrad as en Colombia S.A. Rev. Acad. Colomb. Cienc. Exac. Fis. Nat. $14: 5+81$. 
PIFANO, F. \& ORTIZ, I., 1952. Representantes Venezoelanos del genero Phlebotomus Rondani, 1840 (Diptera, Psy chodid ae). Rev. Venez. Sanid. Asist. Soc. $17: 135-151$.

PIFANO, F.; ORTIZ, I. \& ALVAREZ, A., 1962. Bases taxonomicas para el conocimiento de los Phlebotomus de la region de Guatopo, Venezuela. Arch. Venez. Med. Trop. Parasit. Med. 4 $: 369.428$.

RAMIREZ-PEREZ, J.; MARTINS, A.V. \& RAMIREZ, A., 1976. Lutzomyia conviti n.sp. de flebotomíneo da Venezuela (Dip tera: Psychodidae, Phlebotominae). Rev. Bras. Biol. $36: 599-603$.

READY, P.D.; FRAIHA, H.; LAINSON, R. \& SHAW, J.J., 1981. Current debate on classification of phlebotom me sand flies. Trans. Roy. Soc. Trop. Med. Hyg. 75 :902-903.

RUTLEDGE, L.C.; ELLENWOOD, D.A. \& JOHNSTON, L., 1975. An analysis of sand fly light trap collections in the Panama Canal Zone (Diptera: Psychodidae). J. Med. Ent. 12 :179-183.

RUTLEDGE, L.C.; WALTON, B.C.; ELLENWOOD, D.A. \& CORREA, M.A., 1976. A transect study of sand fly populations in Panama (Diptera: Psychodidae) Env. Ent. $5: 1149-1154$.

SHERLOCK, I.A., 1962. Sobre alguns Phlebotomus e Brumptmoyia da Colômbia (Diptera: Psychodidae). Mem. Inst. Oswaldo Cruz $60: 321-336$.

SHERLOCK, I.A. \& PESSOA, S.B., 1964. Métodos práticos para a captura de flebótomos. Rev. Bras. Biol. $24: 331-340$.

THEODOR, O., 1965. On the classification of American Phlebotominae. J. Med. Ent. 2 :171-197.

VARGAS, L. \& DIAZ-NÄJERA, A., 1951. Phlebotomus pratti. n.sp. de Iguala Estado de Guerrero (Insecta: Diptera) Bol. Inst. Est. Med. Biol. Univ. Nac. Mex. $9: 19-23$.

WARD, R.D.; SHAW, J.J.; LAINSON, R. \& FRAIHA, H., 1973. Leishmaniasis in Brazil. VIII. Observations on the phlebotomine fauna of an area highly endemic for cutaneous leishmaniasis in the Serra dos Carajás, Pará State. Trans. Roy. Soc. Trop. Med. Hyg. 67 :174-183.

WILLIAMS, P., 1970. Phlebotomine sand flies and leishmaniasis in British Honduras (Belize). Trans. Roy. Soc. Trop. Med. Hyg. $64: 317-368$.

YOUNG, D.G., 1979. A review of the Bloodsucking flies of Colombia (Diptera: Phlebotominae \& Sycoracinae) Univ. of Florid a, Gainesville, $266 \mathrm{pp}$. 